\title{
Origin of kamafugite magmas in the East African Rift of western Uganda
}

\author{
Anja Rosenthal $^{1,2}$, Stephen F. Foley ${ }^{1,2}$, D. Graham Pearson ${ }^{3}$, Geoff M. Nowell ${ }^{3}$ and \\ Sebastian Tappe ${ }^{1,4}$ \\ ${ }^{1}$ Institute of Geoscienes, University of Mainz, Becherweg 21, 550099 Mainz, Germany \\ ${ }^{2}$ Research School of Earth Sciences, The Australian National University, Canberra ACT 0200, Australia \\ ${ }^{3}$ Department of Earth Sciences,Durham University, Durham, England \\ ${ }^{4}$ Department of Earth and Atmospheric Sciences, University of Alberta,Edmonton, Alberta, Canada
}

\section{Introduction}

Kamafugites of the Toro Ankole volcanic field in and adjacent to the western branch of the East African Rift provide an excellent opportunity to study the spatial and temporal variation of magma compositions within a major continental rift underlain by a Palaeoproterozoic-Archean basement complex (Tanzanian and Congo cratons; Fig. 1). Here, we present $\mathrm{Sr}, \mathrm{Nd}$, Hf and Os isotope data for the Ugandan kamafugites, and use them to constrain their source characteristics and petrogenesis.

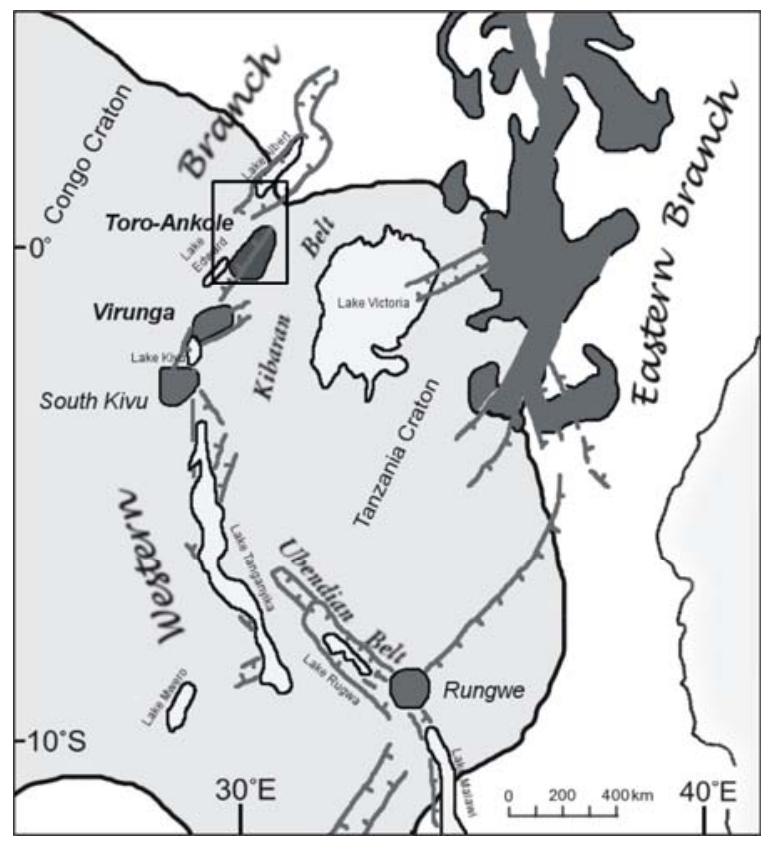

Fig. 1 Simplified map of the equatorial part of the western and eastern branches of the East African Rift.

\section{Major elements and compatible trace elements}

The archetypal Ugandan kamafugites are rare silicaundersaturated, calcium-rich igneous rocks. Their acronym refers to old local petrographically defined names such as katungite, mafurite and ugandite (Sahama, 1974). The presence of modal kalsilite, leucite and perovskite in the volatile-rich, potassic to ultrapotassic kamafugitic magmas is an expression of low contents of silica $\left(\mathrm{SiO}_{2}=31.8-41.8 \mathrm{wt} \%\right.$; Fig. 2), low $\mathrm{Al}_{2} \mathrm{O}_{3}(<8.0 \mathrm{wt} \%)$, and high $\mathrm{CaO}$ contents $(\leq 16.6$ wt $\%)$. They have high $\mathrm{MgO}(\leq 22 \mathrm{wt} \%), \mathrm{Ni}, \mathrm{Cr}$ and $\mathrm{Os}$ concentrations, and high $\mathrm{Mg \#}$. Rarer nephelinites are more evolved with lower Mg\#.

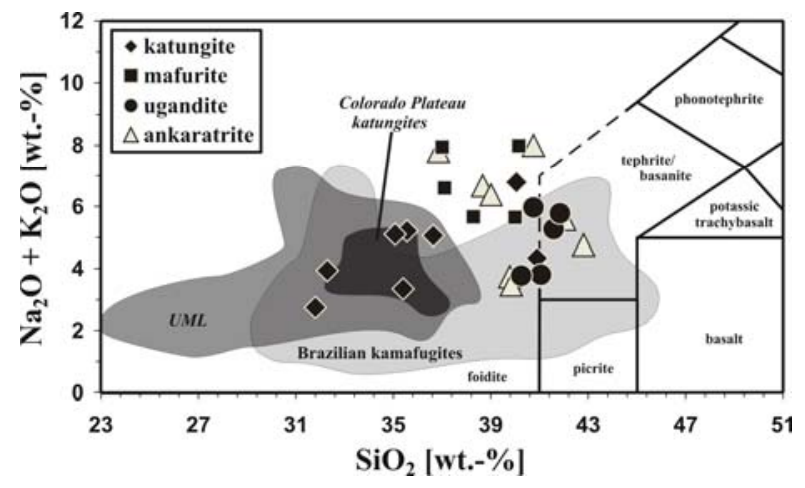

Fig. 2. Total alkali - silica classification diagram of Toro Ankole kamafugites (solid symbols) and ankaratrites (open symbols).

As illustrated in Figure 2, katungites resemble most Colorado and Brazilian kamafugites as well as ultramafic lamprophyres in composition. The high alkali content Ugandan kamafugites is due to potassium enrichment.

\section{Incompatible trace elements}

The extreme and similar enrichments of incompatible trace elements in Ugandan, Colorado and Brazilian kamafugites is striking, with LREE, HFSE and LILE being most enriched and the HREE least enriched (Fig. 3). However, their prominent negative $\mathrm{K}$ and $\mathrm{P}$ anomalies contrast with their significant $\mathrm{K}_{2} \mathrm{O}$ and $\mathrm{P}_{2} \mathrm{O}_{5}$ enrichment, indicating exceptional enrichment in incompatible trace elements. 


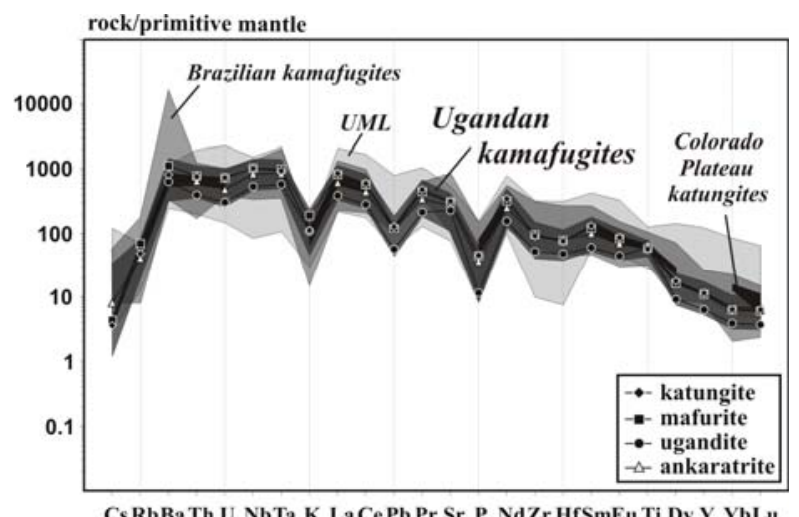

Fig. 3 Average trace element abundances in Ugandan kamafugites normalized to primitive mantle values.

Isotope analyses show that crustal contamination did not play a major role. The latter is demonstrated by a horizontal array on a plot of ${ }^{87} \mathrm{Sr} /{ }^{86} \mathrm{Sr}$ vs. $\mathrm{Mg \#}$, and by negative $\mathrm{Pb}$ troughs in trace element patterns (Fig. 3). This contrasts with positive $\mathrm{Pb}$ in kamafugites which has been shown to originate from sources involving the crust (Prelevic et al., 2005; Prelevic \& Foley, 2007).

\section{Constraints from Sr-Nd-Hf isotopic compositions}

The correlation of enriched $\mathrm{Nd}$ and $\mathrm{Hf}$ isotopic compositions $\left(\varepsilon_{\mathrm{Nd}}=0.08\right.$ to -4.70 and $\varepsilon_{\mathrm{Hf}}=3.64$ to 8.84 ) indicate time-integrated enrichment of the source, which is attributed to carbonate-rich melt infiltration (Fig. 4).

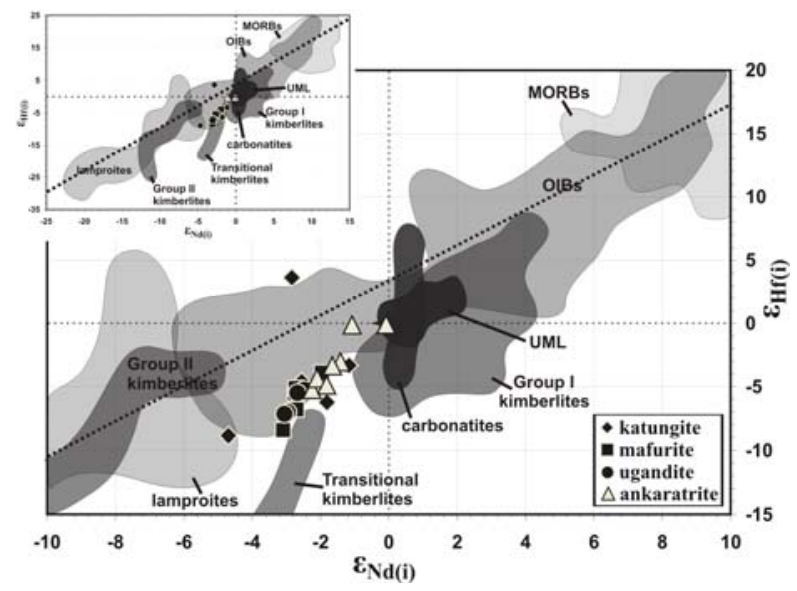

Fig. $4 \varepsilon_{\mathrm{Hf}}$ versus $\varepsilon_{\mathrm{Nd}}$. Hf isotopic compositions of ToroAnkole kamafugites show a much wider range than $\mathrm{Nd}$, distributed along the lower edge of the OIB field, and mainly below the mantle regression line. The latter characteristic is analogous to some lamproites, kimberlites, alkaline basalts and garnet pyroxenites. (e.g. Nowell et al., 2004; 2008; Janney et al., 2002; Pearson \& Nowell, 2004; Tappe et al., 2007). Data from Nowell et al. (2008) are not displayed in this figure.

In contrast, the restricted range of ${ }^{87} \mathrm{Sr} /{ }^{86} \mathrm{Sr}(0.704599$ to 0.705402$)$ of the lavas - intermediate between those of the enriched Virunga province and the more isotopically depleted South Kivu province - indicate recent enrichment of potassium (Fig. 5). Hence, the formation of phlogopite in the source, which is required by the potassic chemistry of the kamafugites, must have occurred shortly before eruption, otherwise more marked growth of ${ }^{87} \mathrm{Sr} /{ }^{86} \mathrm{Sr}$ would have occurred.

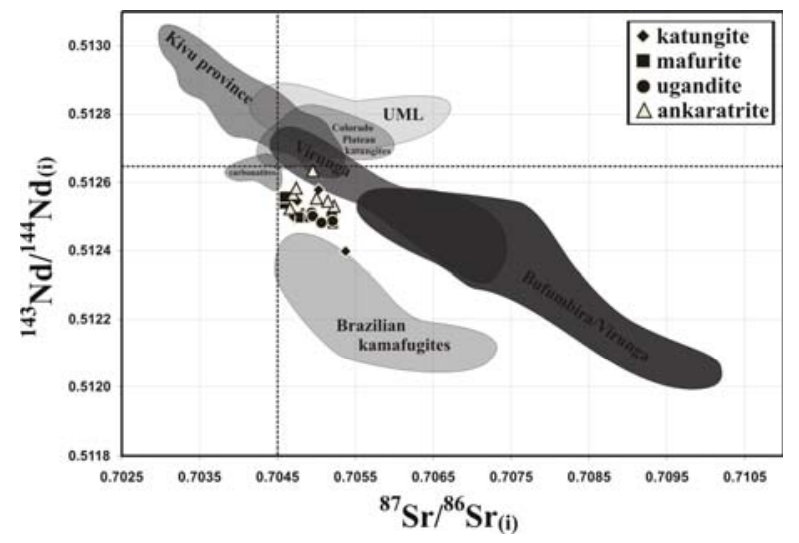

Fig. $\quad 5 \quad{ }^{143} \mathrm{Nd} /{ }^{144} \mathrm{Nd}$ versus ${ }^{87} \mathrm{Sr} /{ }^{86} \mathrm{Sr}$. Toro-Ankole kamafugites and ankaratrites lie well below the array defined by other western rift volcanics.

\section{The mantle source of Ugandan kamafugites}

Isotopes and trace elements are consistent with mixed source components, favouring discrete vein assemblages over enrichment of the mantle lithosphere by pervasive metasomatism. The carbonatitic and alkaline silicate (phlogopite pyroxenite) vein assemblages melted and reacted with peridotitic mantle. This is evident from mixing-curves on plots of $\gamma_{\text {Os }}$ vs. ${ }^{87} \mathrm{Sr} /{ }^{86} \mathrm{Sr}, \gamma_{\text {Os }}$ vs. Os content (Fig. 6), and also $\gamma_{\text {Os }}$ vs. $\mathrm{Ni}$ and $\mathrm{MgO}$ content. High Os concentrations and low $\gamma_{O s}$ of perditotite contrast with low Os content but high $\gamma_{O s}$ of the end-member derived from the ultramafic veins.

In addition, the well-defined inverse curves of radiogenic Os isotopic composition versus Os (Fig. 6; and also of $\gamma_{\mathrm{Os}}$ vs. $\mathrm{Ni}, \mathrm{MgO}$ content) suggest also mixing between peridotite and an enriched endmember in refractory elements.

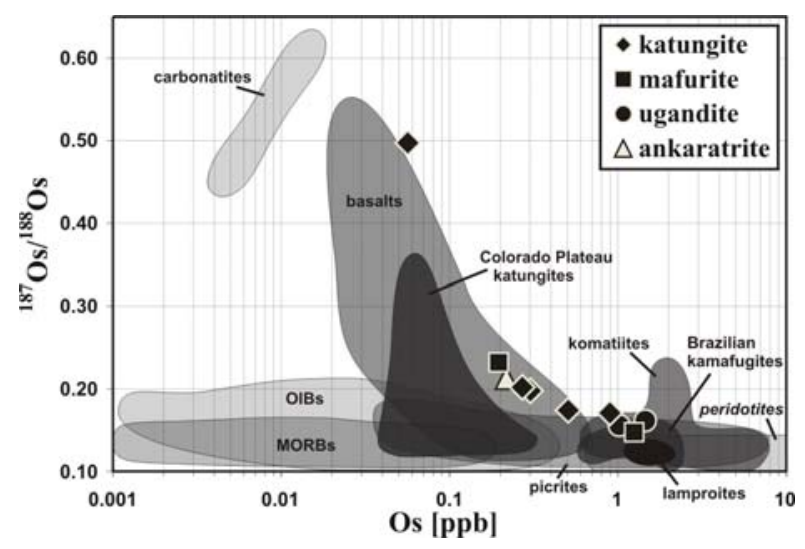

Fig. $6{ }^{187} \mathrm{Os} /{ }^{188}$ Os versus Os content. 
Such suprachondritic Os isotopic composition as well as elevated $\mathrm{Os}, \mathrm{Ni}$ and $\mathrm{MgO}$ concentrations in the Ugandan kamafugites cannot be derived from the convecting mantle. The radiogenic $\gamma_{O s}$ require timeintegrated elevated $\mathrm{Re} / \mathrm{Os}$ ratios known to be formed by partial melts of peridotitic mantle material.

However, the trends seen in the volcanic rock data cannot be fit by mixing curves between two fixed endmembers, but good fits result if petrologically reasonable variation within each of these end-members is permitted. Isotope modeling indicates that the bulk of the melt composition originates in the pyroxenite veins, with a lesser contribution from the peridotite; this is also consistent with curved trends on plots of Os concentrations against $\mathrm{Ni}$ and $\mathrm{MgO}$.

Two-stage enrichment of silicate melts and carbonate melts at approximately $120-180 \mathrm{~km}$ depth within the lithosphere is also known from geochemically similar ultramafic lamprophyres (Tappe et al., 2007). Both magma types, the Ugandan kamafugites and ultramafic lamprophyres, represent the earliest and deepestderived magmatic products of rifts through thick continental lithosphere.

\section{References}

The complete reference list for the data in the figures is available on request from anja.rosenthal@anu.edu.au.

Janney, P.E., Le Roex, A.P., Carlson, R.W., Viljoen, K.S., 2002. A chemical and multi-isotope study of the Western Cape olivine melilitite province, South Africa: Implications for the sources of kimberlites and the origin of the HIMU signature in Africa. Journal of Petrology 43, 2339-2370.

Nowell, G.M., Pearson, D.G., Bell, D.R., Carlson, R.W., Smith, C.B., Kempton, P.D., Noble, S.R., 2004. Hf isotope systematics of kimberlites and their megacrysts: new constraints on their mantle source regions. Journal of Petrology 45, 1583-1612.

Nowell, G.M., Pearson, D.G., Irving, A.J., 2008. Lu-Hf and Re-Os isotopic studies of lamproite genesis. $9^{\text {th }}$ International Kimberlite Conference Extended Abstract No. 9IKC-A-00151.

Pearson, D.G., Nowell., G.M., 2004. Re-Os and Lu-Hf isotope constraints on the origin and age of pyroxenites from the Beni Bousera peridotite massif: implications for mixed peridotitepyroxenite mantle sources. Journal of Petrology 45, 439-355.

Prelevic, D., Foley, S.F., Romer, R.L., Cvetkovic, V., Downes, H., 2005. Tertiary ultrapotassic volcanism in Serbia: Constraints on petrogenesis and mantle source characteristics. Journal of Petrology 46, 1443-1487.

Prelevic, D., Foley, S.F., 2007. Accretion of arcoceanic lithospheric mantle in the Mediterranean: Evidence from extremely high-Mg olivines and $\mathrm{Cr}$ - rich spinel inclusions in lamproites. Earth and Planetary Science Letters 256, 120-135.

Sahama, T.G., 1974. Potassium-rich alkaline rocks. In: H. Sorensen, (Ed), The Alkaline Rocks, Wiley, London, 96-109.

Tappe, S., Foley, S.F., Stracke, A., Romer, R.L., Kjarsgaard, B.A., Heamann, L.M., Joyce, N., 2007. Craton reactivation on the Labrador Sea margins: Ar-40/Ar-39 age and Sr-Nd-Hf-Pb isotope constraints from alkaline and carbonatite intrusives. Earth and Planetary Science Letters 256, 433-454. 